\title{
The occurrence of branchiobdellidans on stone crayfish (Austropotamobius torrentium) in the Czech Republic
}

\author{
Pavel Vlach $^{1, *}$, Lucie Šrámková ${ }^{1}$, Kateřina Fialová ${ }^{2}$ and Klára Nováková ${ }^{3}$ \\ ${ }^{1}$ Faculty of Education of the University of West Bohemia, Center of Biology, Geosciences and Environmental Education, Klatovská 51, \\ 30619 Plzen, Czech Republic \\ ${ }^{2}$ Faculty of Nuclear Sciences and Physical Engineering of Czech Technical University in Prague, Břehová 7, 11519 Praha 1, \\ Czech Republic \\ ${ }^{3}$ Old College, South Bridge, Edinburgh EH8 9YL, Scotland
}

\begin{abstract}
The stone crayfish Austropotamobius torrentium (Schrank, 1803) is one of only two native crayfish species in the Czech Republic. Epibiotic branchiobdellidans present on this crayfish species have not been studied before in the Czech Republic. Here we evaluate the occurrence, and basic population characteristics of branchiobdellidans inhabiting A. torrentium in 12 small streams in the Czech Republic. Three Branchiobdella species were found: Branchiobdella parasita, and B. pentadonta dominated. $B$. hexadonta was found only exceptionally, as we did not focus on species inhabiting the gill chamber. The overall abundance varied between 0.3 and 17 individuals per crayfish. The mean length of $B$. parasita was 3.58 (1.1-7.1) mm, of B. pentadonta $2.00(0.9-4.9) \mathrm{mm}$, and of B. hexadonta 1.73 (1.4-2.2) $\mathrm{mm}$.
\end{abstract}

Keywords: Austropotamobius torrentium / epibionts / branchiobdellidans / Czech Republic

Résumé - Occurence de branchiobdellidés sur l'écrevisse des torrents (Austropotamobius torrentium) en République tchèque. L'écrevisse des torrents Austropotamobius torrentium (Schrank, 1803) est l'une des deux espèces d'écrevisses natives de la République tchèque. Les branchiobdellidés épibiotiques présents sur cette espèce d'écrevisse n'ont pas été étudiés avant en République tchèque. Ici, nous évaluons l'apparition et les caractéristiques démographiques de base des branchiobdellidés épibiontes d'A. torrentium dans 12 petits cours d'eau en République tchèque. Trois espèces de Branchiobdelle ont été trouvées: Branchiobdella parasita et $B$. pentadonta ont dominé. $B$. hexadonta n'a été trouvée que de façon exceptionnelle, car nous ne nous sommes pas concentrés sur les espèces qui occupent la chambre branchiale. L'abondance globale variait entre 0,3 et 17 individus par écrevisse. La longueur moyenne de $B$. parasita était de 3,58 (1,1-7,1) mm, de B. pentadonta $2,00(0,9-4,9) \mathrm{mm}$ et de B. hexadonta $1,73(1,4-2,2) \mathrm{mm}$.

Mots-clés : Austropotamobius torrentium / epibionte / branchiobdellidé / République Tchèque

\section{Introduction}

The stone crayfish Austropotamobius torrentium (Schrank, 1803 ) is one of only two native crayfish species in the Czech Republic (Souty-Grosset et al., 2006; Kouba et al., 2014). Presently, this species inhabits more than 40 streams in the western part of Bohemia, in Central Bohemia (streams in the Landscape Protected Area (LPA) Krrivoklátsko and a few streams near the town of Prague), as well as in Bohemian Uplands (isolated localities in LPA České středohoří) and one introduced locality in the Giant Mountains (Kozák et al., 2002; Vlach et al., 2009; Petrusek et al., 2017, see Fig. 1). The stone

\footnotetext{
*Corresponding author: vlach.pavel@mybox.cz
}

crayfish is a critically endangered species in the Czech Republic according to Czech law (114/1992), has an IUCN "data deficient" status (Füreder et al., 2010) and is among priority species given by the Council Directive 92/43/EEC.

Branchiobdellidans are considered to be epizootic commensals with a transition to facultative parasitism or mutualistic cleaners, and they prefer to live on crayfish (Govendich et al., 2010; Rosewarne et al., 2012; Skelton et al., 2013). These epibionts mainly invade the body surface, gills, and occasionally the gill chamber, using a sucker (Bádr, 2000; Duriš et al., 2006; Lee et al., 2009; Skelton et al., 2013). The influence of branchiobdellidans can be negative if they feed on crayfish tissues, and in extreme cases they can even kill the crayfish (Bádr, 2000; Souty-Grosset et al., 2006; Rosewarne et al., 2012). 


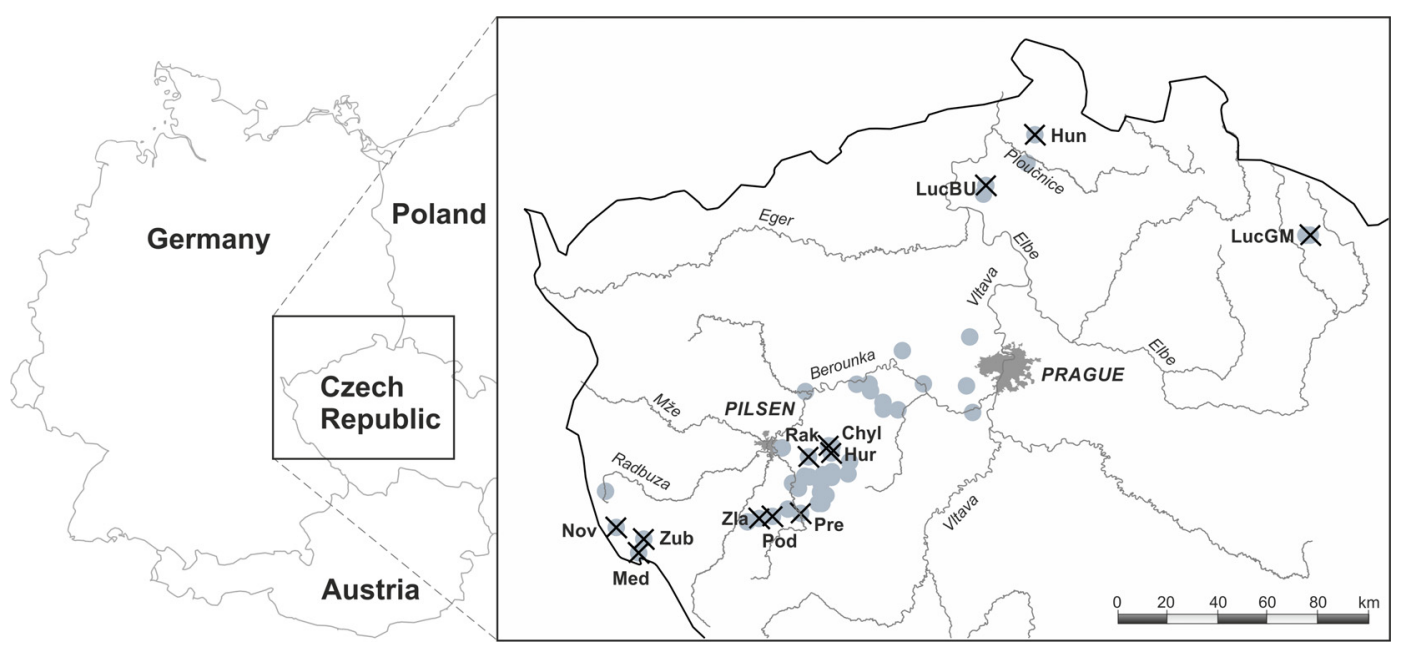

Fig. 1. Map of the Czech Republic with the locations of the examined streams. Grey circles: occurrence of $A$. torrentium in the Czech Republic according to Vlach et al. (2009), crosses: the examined streams (for abbreviations see Tab. 1).

However, other studies have found a positive influence associated with the removal of algae from crayfish gills (Lee et al., 2009; Skelton et al., 2013). In addition, there are studies describing a strong mutualistic relationship between branchiobdellidans and crayfish, expressing the fact that the high abundance of worms leads to good body condition of crayfish (Védia et al., 2016).

Branchiobdellidans live in the holarctic region (Gelder, 1999; Füreder et al., 2009). There are eight endemic species in Europe: Branchiobdella parasita (Braun, 1805), B. astaci Odier, 1823, B. hexadonta Gruber, 1883, B. italica Canegallo, 1928, B. pentadonta Whitman, 1882, B. balcanica Moszyński, 1938 (Gelder, 1999; Füreder et al., 2009; Subchev and Gelder, 2010; Subchev, 2012, 2014), B. kozarovi Subchev, 1978 (Subchev, 1978, 2014; Fard and Gelder, 2011) and B. papilosa Nesemann and Hutter, 2002 (Nesemann and Hutter, 2002; Subchev, 2011).

Branchiobdellidans in the Czech Republic have not been studied intensively in the past, with only a few studies concerning these worms on Astacus astacus (Straškraba, 1956; Bádr, 2000) and Orconected limosus (Duriš et al., 2006). An important contribution to Czech branchiobdellidans was made by Subchev (2012), who studied worms on crayfish from a collection in the London Natural History Museum. Moreover, there are some "grey" works focused on this topic, e.g., Nováková and Fialová (2012), Šrámková (2014) or Ložek (2015). Most of these data were also reviewed by Subchev (2014). Based on these papers six species have been identified so far in the Czech Republic: Branchiobdella astaci, $B$. balcanica, B. hexadonta, B. italica, B. parasite and B. pentadonta (Straškraba, 1956; Bádr, 2000; Duriš et al., 2006; Subchev and Gelder, 2010; Subchev, 2012, 2014).

The occurrence of branchiobdellidans on the stone crayfish A. torrentium was studied mainly in Southern and Eastern Europe, e.g., in Greece (Subchev et al., 2007), Macedonia (Subchev, 2012; Rimcheska et al., 2014), Albania (Subchev, 2011), Croatia (Klobučar et al., 2006) and Hungary (Kovács and Juhász, 2007). There is also some information from Central Europe, e.g., Germany (Subchev, 2013) and Austria (Füreder et al., 2009). Concluding the results of the above- mentioned papers, only three branchiobdellans were recorded on A. torrentium: B. parasita, B. pentadonta and B. hexadonta. However, two more Branchiobdella species, B. italica and $B$. astaci were found on a related species, $A$. pallipes, in Italy (Gelder, 1999; Mori et al., 2001; Gherardi et al., 2002; Oberkofler et al., 2002; Skalici et al., 2010), Croatia (Klobučar et al., 2006) or in the UK (Rosewarne et al., 2012).

Here we report the occurrence and basic morphometry of branchiobdellidans on the stone crayfish $A$. torrentium in the Czech Republic, based on newly determined data from worm collections that were analysed in the unpublished works of Nováková and Fialová (2012) and Šrámková (2014).

\section{Material and methods}

Branchiobdellidans were collected from 2011 to 2013. In total, worms from 12 stream inhabited by $A$. torrentium (from more than 40 of these streams in the Czech Republic, see Vlach et al., 2009) were analysed. The names and abbreviations of the streams, as well as the number of crayfish used for analyses are given in Table 1, while the basic morphological character of the examined streams are described in Vlach et al. (2009).

At each locality, individuals of $A$. torrentium were caught using a standard method consisting of searching through all the possible shelters (e.g., turning over stones) using hands and a hand net. Crayfish were collected as a part of standard $A$. torrentium monitoring programme led by Nature Conservation Agency of the Czech Republic (collectors were also the owners of the exception to the Czech law no. 114 enabling them to manipulate with this critically endangered species). From the crayfish caught, a set of 9-19 specimens was chosen depending on the availability of crayfish in each stream. Following the method of Gelder et al. (1994), individuals of this set were anaesthetized in a solution of brook water and carbonated water (bottled mineral water) mixed in a ratio of 1:1 for $2 \mathrm{~min}$. The total length of each crayfish (TL) was measured using a calliper. Individuals of branchiobdellidans dwelling on the crayfish surface (not in the gill chamber) were then removed with tweezers and fixed in $70 \%$ ethanol. 
Table 1. The examined localities, abbreviations, numbers of $A$. torrentium analysed, the mean total length in $\mathrm{mm}$ (TL) and standard deviation (SD) of $A$. torrentium from which branchiobdellidans were collected.

\begin{tabular}{llllr}
\hline Locality & Abbreviation & $N$ & TL (mm) & SD \\
\hline Luční brook (Giant Mnts.) & LucGM & 15 & 66.8 & 16.4 \\
Huníkovský brook & Hun & 14 & 60.2 & 9.9 \\
Luční brook (Bohem. Uplands) & LucBU & 15 & 63.7 & 8.0 \\
Chýlava & Chyl & 11 & 55.1 & 11.2 \\
Hurecký brook & Hur & 15 & 56.4 & 10.7 \\
Rakovský brook & Rak & 9 & 42.3 & 9.6 \\
Přešínský brook & Pre & 15 & 59.7 & 8.1 \\
Podhrázský brook & Pod & 15 & 64.9 & 8.3 \\
Zlatý brook & Zla & 15 & 54.8 & 8.5 \\
Zubřina & Zub & 18 & 63.7 & 16.1 \\
Novosedlský brook LT & Nov & 19 & 52.4 & 11.1 \\
Medvědí brook & Med & 19 & 48.6 & 10.0 \\
\hline
\end{tabular}

Table 2. Numbers of individual species, total numbers and the mean abundance of branchiobdellidans per one crayfish in the studied streams (Bpar: B. parasita, Bpen: B. pentodonta, Bhex: B. hexadonta, and $\mathrm{BpC}$ : the mean number of branchiobdellidans per one crayfish specimen).

\begin{tabular}{lrrlrr}
\hline Locality & Bpar & Bpen & Bhex & Total & BpC \\
\hline Luční brook (Giant Mnts.) & 86 & 35 & 0 & 121 & 8.1 \\
Huníkovský brook & 57 & 20 & 3 & 80 & 5.7 \\
Luční brook (Bohem. Uplands) & 48 & 1 & 0 & 49 & 3.3 \\
Chýlava & 46 & 45 & 0 & 91 & 8.3 \\
Hurecký brook & 25 & 4 & 0 & 29 & 1.9 \\
Rakovský brook & 25 & 6 & 0 & 31 & 3.4 \\
Přešínský brook & 71 & 6 & 0 & 77 & 5.1 \\
Podhrázský brook & 22 & 0 & 0 & 22 & 1.5 \\
Zlatý brook & 15 & 1 & 1 & 17 & 1.1 \\
Zubřina & 14 & 292 & 0 & 306 & 17.0 \\
Novosedlský brook LT & 35 & 0 & 0 & 35 & 1.9 \\
Medvědí brook & 3 & 2 & 0 & 5 & 0.3 \\
Total & 447 & 412 & 4 & 863 & 4.8 \\
\hline
\end{tabular}

The identification of all removed branchiobdellidans was performed using an optical microscope (magnification 100 $400 \times$, Intraco Micro LM 600) on the basis of body shape and morphology, the configuration of cuticle teeth, as well as the shape of the spermathecal, as used by, e.g., Subchev (1984) and Gelder et al. (1994), while taking into account new European species and their morphology (Nesemann and Hutter, 2002; Subchev and Gelder, 2010; Subchev, 2014).

The normality of sample distribution was examined using the Kolmogorov-Smirnov test. The length structures of stone crayfish from individual streams were compared using nonparametric one-way analysis of variance (Kruskal-Wallis ANOVA). The length structure of particular Branchiobdella species was also compared using one-way analysis of variance

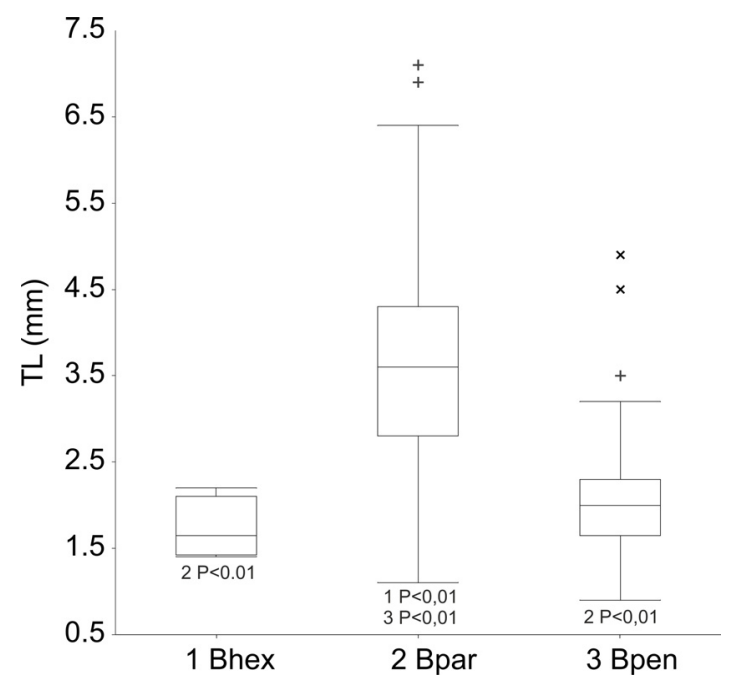

Fig. 2. The length structure of particular Branchiobdella species. Bhex: B. hexadonta, Bpar: B. parasita, and Bpen: B. pentadonta (median, inter-quartile range (IQR), the largest value/the smallest value smaller/bigger than 1.5 times IQR, extremes + lower $(\times$ higher $)$ than 3 times IQR).

(ANOVA). A multiple comparison was also made using Tukey-Kramer test. All tests were carried out at a significance level of $5 \%(P<0.05)$ using the NCSS 9.0 software pack.

\section{Results}

Branchiobdellidans were found at all localities where crayfish were caught and examined. A total of three Branchiobdella species were recorded: $B$. parasita and $B$. pentadonta dominated, while $B$. hexadonta occurred exceptionally.

B. parasita occurred at all observed localities and dominated at most (LucGM, Hun, LucBU, Rak, Pre, Pod, Zla, Nov). In two streams, there were equal occurrences of $B$. parasita and $P$. pentadonta (Hur, Med), and $B$. pentadonta dominated in one stream (Zub). B. hexadonta was observed in only two streams (Hun, Zla). The mean abundance of branchiobdellidans per one crayfish individual varied between 0.3 (Med) and 17.0 (Zub). For more details see Table 2.

In addition, the body lengths of particular branchiobdellidans differed significantly $(H=216.32, P<0.01$, Fig. 2$)$. The mean length of $B$. parasita was $3.58 \mathrm{~mm}$ (minimum 1.1 maximum 7.1), which was significantly larger than other species (Tukey-Kramer multiple test, $P<0.01$ ). The mean length of $B$. pentadonta was $2.00(0.9-4.9)$, and the mean length of $B$. hexadonta was 1.73 (1.4-2.2). The body lengths of these species did not significantly differ $(P=0.85)$.

\section{Discussion}

Six species of Branchiobdella species have been found so far in the Czech Republic. Historically, Straškraba (1956) described $B$. hexadonta and B. pentadonta. Bádr (2000) found $B$. parasita and $B$. italica on $A$. astacus. However, the identification of $B$. italica was only carried out on the basis of 
cuticle teeth, and was later corrected by Čermáková and Bádr (2002). The occurrence of B. italica was also reported by Nováková and Fialová (2012), with the same misidentification; all $B$. italica reported from the Přešínský brook were in fact $B$. pentadonta. In fact, $B$. italica have not yet been found on $A$. torrentium, but on A. pallipes in Italy and Croatia (Gelder, 1999; Mori et al., 2001; Gherardi et al., 2002; Oberkofler et al., 2002; Klobučar et al., 2006; Skalici et al., 2010).

Duriš et al. (2006) reported B. parasita, B. pentadonta, $B$. hexadonta and B. balcanica on O. limosus in the Elbe River in Obříství (Central Bohemia). Subchev (2012) recently studied crayfish from the Czech Republic in the London Natural History Museum collections; in this collection he found three species (B. pentadonta, B. hexadonta and B. parasita) and also found $B$. astaci on the noble crayfish Astacus astacus. This was the first description of this Branchiobdella species from the Czech Republic.

In this study we identified B. parasita, B. pentadonta and $B$. hexadonta. No other branchiobdellans have been found on A. torrentium as mentioned by many authors (Klobučar et al., 2006; Kovács and Juhász, 2007; Subchev et al., 2007; Füreder, 2009; Subchev, 2011, 2012, 2013; Rimcheska et al., 2014; also reviewed by Subchev, 2014).

The most common species at each locality were $B$. parasita and $B$. pentodonta. These species are among the most common species of the Branchiobdella genus in Europe, and their occurrence has been reported by many authors in different European countries (e.g., Gelder et al., 1994; Duriš et al., 2006; Klobučar et al., 2006; Subchev et al., 2007; Subchev and Gelder, 2010; Subchev, 2012 and reviewed by Subchev, 2014).

Branchiobdella hexadonta is also very common European branchiobdellidans (Subchev, 2014). We found only a few individuals of this species, as we only collected worms dwelling on the crayfish body and not in the gill chamber where this species usually occur if present (Skelton et al., 2013; Subchev, 2014). The species was recorded for the first time on $A$. torrentium in the Czech Republic. B. astaci is another species inhabiting the gill chamber (Subchev, 2014) and Šrámková (2014) mentioned the occurrence of this species in the left tributary of the Novosedlský brook. Nevertheless, this individual was identified incorrectly and the studied worm was most likely B. parasita (M. Subchev, in lit.). In fact, the presence of $B$. astaci in the Czech Republic has only been recorder once (Subchev, 2012). On the other hand, B. astaci was frequently found in the UK on the related crayfish, A. pallipes, as this worm is the only European one living in the UK, except for two invasive species Xironogiton victoriensis and Cambarincola aff. okadai inhabiting introduced Pacifastacus leniusculus (James et al., 2015) there.

Despite the findings of Duriš et al. (2006) and other findings of $B$. balcanica reported in many Central European countries by Subchev (2014), we were unable to confirm the occurrence of this worm. Taking into account the Balcan origin of the A. torrentium in Luční brook in the Giant Mountains (Petrusek et al., 2017), we assumed a possibility of detecting $B$. balcanica there. Nevertheless, $B$. balcanica has never been reported as being present on $A$. torrentium. B. kozarovi has also never been found on $A$. torrentium, and its presence has never been observed in the Czech Republic. This is not surprising considering its East European distribution (Kolesnikova and Utevsky, 2003; Fard and Gelder, 2011; Subchev, 2012, 2014).
In conclusion, only three Branchiobdella species were found on A. torrentium until now. However, as other Branchiobdella species are present on ecologically similar or related crayfish species, inhabiting the same watershed or living sympatrically, there is no reason not to expect the presence of other species.

The mean abundance of branchiobdellidans in the particular streams studied here varied significantly, but the values are comparable to abundances mentioned in other papers. Skalici et al. (2010) reported 6.9 individuals per crayfish in northern Italy, while Gelder et al. (1994) even found abundances in the range of 9.8-20 branchiobdellidans per one crayfish. The largest population was observed in Greece, with an abundance of 145.5 individuals per one crayfish (Subchev et al., 2007). This variability is not surprising as the branchiobdellidans abundance depends on many factors; Védia et al. (2016) pointed out the positive relationship between biochemical oxygen demand, phosphates, coliforms, potassium and branchiobdellans abundance. Moreover, a higher abundance of these worms on large crayfish individuals is known generally, providing them with more surface for their life and reproduction and also avoiding frequent molting (Mori et al., 2001; DeWitt et al., 2013; Védia et al., 2016).

The body lengths of branchiobdellidans found here mostly correspond to those from other studies (Subchev, 1984, 2014; Füreder et al., 2009).

Acknowledgements. We would like to thank Prof. Mitko Suchev for his cooperation and support during the species identifications as well as interesting suggestions that significantly improved this manuscript. We also thank David Hardekopf for improving the language.

\section{References}

Bádr V. 2000. Výskyt potočnic r. Branchiobdella v České republice a jejich možná patogenita - předběžná zpráva. Bull VÚRH Vodnany 36: 33-34.

Čermáková J, Bádr J. 2002. Determinační znaky evropských zástupcu trrídy Branchiobdellae. In: Bryja J, Zukal J, eds. Zoologické dny Brno 2002, Sborník abstraktu z konference 14.-15. února 2002. Brno: Ústav biologie obratlovcu AV ČR, pp. 22-23 (in Czech).

DeWitt PD, Williams BW, Lu Z-Q, Fard AN, Gelder SR. 2013. Effects of environmental and host physical characteristics on an aquatic symbiont. Limnologica 43: 151-156.

Ďuriš Z, Horká I, Kristian I, Kozák P. 2006. Some cases of macroepibiosis on the invasive crayfish Orconectes limosus in the Czech Republic. Bull Fr Pêche Piscic 380-381: 1325-1337.

Fard AN, Gelder SR. 2011. First report of Branchiobdella kozarovi Subchev, 1978 (Annelida: Clitellata) in Iran, and its distribution in the eastern Euro-Mediterranean Subregion. Acta Zool Bulg 63: 105-108.

Füreder L, Gherardi F, Souty-Grosset C. 2010. Austropotamobius torrentium. The IUCN Red List of Threatened Species 2010, e. T2431A9439449. http://dx.doi.org/10.2305/IUCN.UK.2010-3. RLTS.T2431A9439449.en (cited: 29 June 2017).

Füreder L, Summerer M, Brandstätter A. 2009. Phylogeny and species composition of five European species of Branchiobdella (Annelida: Clitellata: Branchiobdellida) reflect the biogeographic history of three endangered crayfish species. J Zool 279: 164-172.

Gelder SR. 1999. Zoogeography of branchiobdellidans (Annelida) and temnocephalidans (Plathelminthes) ectosymbiontic on freshwater crustaceans, and their reactions to one another in vitro. Hydrobiologia 406: 21-31. 
Gelder SR, Delmastro GB, Ferraguti M. 1994. A report on branchiobdellidans (Annelida: Clitellata) and taxonomic key to the species in northern Italy, including the first record of Cambarincola mesochoreus on the introduced American red swamp crayfish. Boll Zool 61: 179-183.

Gherardi F, Cenni F, Crudele G, Mori M. 2002. Infestation rate of branchiobdellids in Austropotamobius pallipes italicus from a stream of Central Italy: preliminary results. Bull Fr Pêche Piscic 367: 785-792.

Govendich FR, Bain BA, Gelder SR, Davies RW, Brinkhurst RO. 2010. Annelida (Clitella): Oligochaeta, Branchiobdellida, Hirudinia and Acanthobdellida. In: Thorp JH, Covich AP, eds. Ecology and classification of North American freshwater invertebrates, 3rd ed. Burlinhton, USA: Elsevier, pp. 385-436.

James J, Cable J, Richardson G, Davidson KE, Mackie ASY. 2015. Two alien species of 481 Branchiobdellida (Annelida) new to the British Isles: a morphological and molecular study. Aquat Invasions 10: 371-383.

Klobučar GIV, Maguire I, Gottstein S, Gelder SR. 2006. Occurrence of Branchiobdellida (Annelida: Clitellata) on freshwater crayfish in Croatia. Ann Limnol Int J Limnol 42: 251-260.

Kolesnikova MA, Utevsky S. 2003. First record on Branchiobdella kozarovi (Clitellata: Branchiobdellida) from Eastern Ukraine. Lauterbornia 65: 77-81.

Kouba A, Petrusek A, Kozák P. 2014. Continental-wide distribution of crayfish species in Europe: update and maps. Knowl Manag Aquat Ecosyst 413: 5.

Kovács T, Juhász P. 2007. Data to the distribution of crayfish worms (Branchiobdellidae) in Hungary. Folia historiconaturalia Musei Matraensis 31: 77-79.

Kozák P, Duriš Z, Policar T. 2002. The stone crayfish Austropotamobius torrentium (Schrank) in the Czech Republic. Bull Fr Pêche Piscic 367: 707-713.

Lee JH, Kim TW, Choe JC. 2009. Commensalism or mutualism: conditional outcomes in a branchiobdellid-crayfish symbiosis. Oecologia 159: 217-224.

Ložek F. 2015. Společenstvo potočnic na nepuvodních druzích raku ČR, MSc Thesis. University of South Bohemia in České Budějovice, Faculty of Fisheries and Protection of Waters, 38 p. (in Czech with English summary).

Mori M, Pretoni Y, Salvidio S, Balduzzi A. 2001. Branchiobdellid size-crayfish size: a possible relationship. J Limnol 60: 208-210.

Nesemann H, Hutter G. 2002. Krebsegel (Branchiobdellidae: Branchiobdella Odier, 1823) in Vorarlberg (Österreich) mit einer Neubeschreibung von Branchiobdella papillosa n. sp. Forschen und Entdecken Vorarlberger Naturschau 11: 203-214.

Nováková K, Fialová K. 2012. Výskyt potočnic rodu Branchiobdella na raku kamenáči na Plzensku. Středoškolská odborná činnost 2011/2012. Blovice: Gymnázium Blovice, 26 p. (in Czech with English summary).

Oberkofler B, Quaglio F, Füreder L, et al. 2002. Species of Branchiobdellidae (Annelida) on freshwater crayfish in south Tyrol (northern Italy). Bull Fr Pêche Piscic 367: 777-784.

Petrusek A, Pešek P, Leština D, et al. 2017. Mitochondrial DNA provides evidence of a double origin for the stone crayfish Austropotamobius torrentium in the Elbe basin. Limnologica 62: 77-83.
Rimcheska B, Georgieva G, Slaveska-Stamenkovic V, Smijkov S, Uzunov Y, Mitic-Kopanja D. 2014. New data about occurrence of epibiotic Branchiobdellid (Annelida: Branchiobdellea) species on the stone crayfish Austropotamobius torrentium (Schrank, 1803) in the Republic of Macedonia. Acta Zool Bulg 66: 261-263.

Rosewarne P, Mortimer R, Dunn A. 2012. Branchiobdellidan infestation on endangered white-clawed crayfish (Austropotamobius pallipes) in the UK. Parasitology 139: 774-780.

Skalici M, Giulio A, Libertini G. 2010. Biological and morphological aspects of Branchiobdella italica (Annelida: Clitellata) in a native crayfish population of central Italy. Ital J Zool 77: 410-418.

Skelton J, Farrell KJ, Creed RP, et al. 2013. Servants, scoundrels, and hitchhikers: current understanding of the complex interactions between crayfish and their ectosymbiotic worms (Branchiobdellida). Freshw Sci 32: 1345-1357.

Souty-Grosset C, Holdich DM, Noël PY, Reynolds JD, Haffner P, eds. 2006. Atlas of Crayfish in Europe. Paris: Muséum national d'Histoire naturelle, $187 \mathrm{p}$.

Šrámková L. 2014. Stanovištní druhové preference epizoických potočnic rodu Branchiobdella na raku kamenáči, Bc Thesis. Plzen: Západočeská univerzita v Plzni, Fakulta pedagogická, 57 p. (in Czech with English summary).

Straškraba M. 1956. Komensálové v žaberní dutině Astacus astacus L. ze Slezska. Prírodovědecký sborník Ostravského kraje 17: 593 596 (in Czech, with Russian and German summary).

Subchev MA. 1978. A new branchiobdellid - Branchiobdella kozarovi sp. n. (Oligochaeta: Branchiobdellidae) from Bulgaria. Acta Zool Bulg 9: 78-80.

Subchev MA. 1984. On Hungarian branchiobdellids (Oligochaeta: Branchiobdellidae). Miscellanea Zool Hung 2: 47-50.

Subchev MA. 2011. First record of Branchiobdella Odier, 1823 (Annelida: Clitellata) in Albania and overview of the geographic distribution of Branchiobdella hexodonta Gruber, 1882 in Europe. Acta Zool Bulg 63: 109-112.

Subchev MA. 2012. Branchiobdella (Annelida: Clitellata) species found in crayfish collection of London Natural History Museum. Acta Zool Bulg 64: 319-323.

Subchev MA. 2013. Branchiobdella (Annelida: Clitellata) species found in the crayfish collection of the Natural History Museum of Denmark. Acta Zool Bulg 65: 571-572.

Subchev MA. 2014. The genus Branchiobdella Odier, 1823 (Annelida, Clitellata, Branchiobdellida): a review of its European species. Acta Zool Bulg 66: 5-20.

Subchev MA, Gelder SR. 2010. Branchiobdellida (Annelida: Clitellata) found in the crayfish collection of the Natural History Museum in Vienna, Austria, with a re-description of Branchiobdella papillosa Nesemann \& Hutter, 2002. Acta Zool Bulg 62: 33-42.

Subchev MA, Koutrakis E, Perdikaris C. 2007. Crayfish epibionts Branchiobdella sp. and Hystricosoma chappuisi (Annelida: Clitellata) in Greece. Bull Fr Pêche Piscic 387: 59-66.

Védia I, Miranda R, Oscoz J, Baquero E. 2016. Invading the invaders: environmental conditions and relationships of an exotic branchiobdellidan with its exotic host. Inland Waters 6: 54-64.

Vlach P, Hulec L, Fischer D. 2009. Recent distribution, population densities and ecological requirements of the stone crayfish (Austropotamobius torrentium) in the Czech Republic. Knowl Manag Aquat Ecosyst 384-385: 13.

Cite this article as: Vlach P, Šrámková L, Fialová K, Nováková K. 2017. The occurrence of branchiobdellidans on stone crayfish (Austropotamobius torrentium) in the Czech Republic. Knowl. Manag. Aquat. Ecosyst., 418, 39. 